\title{
Moringa oleifera Intake during Pregnancy and Breastfeeding toward Docosahexaenoic Acid and Arachidonic Acid Levels in Breast Milk
}

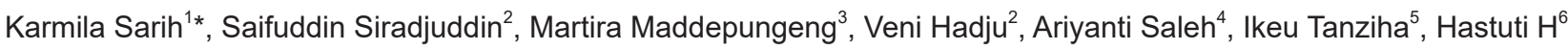 \\ ${ }^{1}$ Department of Nutrition, Public Health Faculty, Universitas Hasanuddin, Makassar, Indonesia; ${ }^{2}$ Department of Nutrition, \\ School of Public Health, Universitas Hasanuddin, Makassar, Indonesia; ${ }^{3}$ Department of Child, Wahidin Sudirohusodo Hospital, \\ Makassar, Indonesia; ${ }^{4}$ Department of Nursing, Nursing Faculty, Universitas Hasanuddin, Makassar, Indonesia; ${ }^{5}$ Department \\ of Community Nutrition, Institut Pertanian Bogor, Bogor, Indonesia; ${ }^{6}$ Department of Nursing, Anging Mammiri Nursing College, \\ Makassar, Indonesia
}

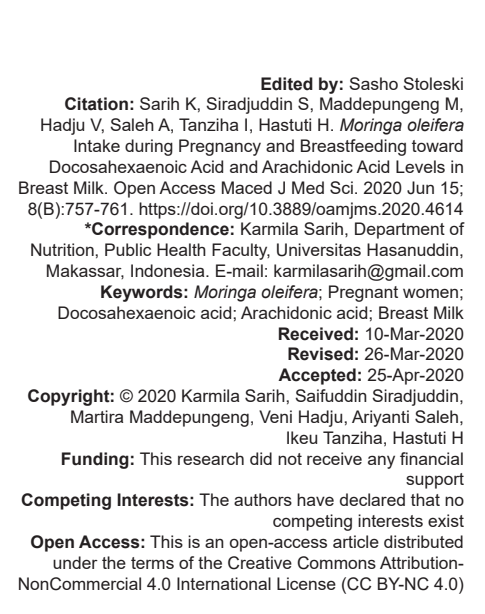

\begin{abstract}
BACKGROUND: Moringa oleifera is a nutritional food supplement that can save lives, particularly in countries with malnourished community. Such supplement can also be provided to breastfeeding mothers so that they can produce more breast milk

AIM: This study investigated the effect of $M$. oleifera on pregnant and breastfeeding mothers on their breast milk's docosahexaenoic acid (DHA) and arachidonic acid (AA) concentration.

METHODS: This was a longitudinal study which was the continuity from the previous experimental study. The research sample was 64 breastfeeding mothers given Moringa leaves powder (MLP), Moringa leaves extract (MLE), or iron-folic acid (IFA). The data were analyzed using Kruskal-Wallis test with the significance level of $95 \%$ aiming to assess the difference between the breast milk's DHA and AA level on MLP, MLE, and IFA groups.

RESULTS: This research indicated that most mothers had low education level $(71.9 \%)$ and did not work $(89.1 \%)$ There was no significant difference between the DHA level $(p=0.215)$ and AA $(p=0.914)$ of the breast milk among the MLP, MLE, and IFA groups.
\end{abstract}

CONCLUSION: The intervention might contribute a little effect on DHA and AA level in the breast milk.

\section{Introduction}

The attempt to have smart, strong, and healthy infants is actualized by feeding them nutritious food. Breast milk is universally known as optimal and ideal food for newborn babies until they reach 6 months old [1], [2]. Over the past two decades, fatty acids are proven as an essential component in breast milk since it gives energy and essential nutrition. It becomes the key component for the development of the central nervous system and it cannot be de novo synthesized by infants [1].

Fatty acids are the essential element in the cell membrane, and highly concentrated docosahexaenoic acid (DHA) is specifically accumulated in the developing brains. DHA and arachidonic acid (AA) play a role in the development of the nervous system, retina, and brain, and both elements are available in breast milk for infants [3]. Nevertheless, lack of nutrition in breastfeeding mothers will influence the ability to supply good nutrition breast milk for the infants' growth and development [4].
One of the potential local food rich in nutrition and abundantly available yet has not been used optimally is Moringa oleifera. This tree is easily found in all areas of Indonesia including South Sulawesi [5]. All parts of M. oleifera are useful, therefore, it is known as "a miracle tree." For medication, all parts of the tree (root, leaves, seeds, tree bark, rubber, and flowers) have been used for curing many diseases. For the nutritional purpose, the leaves can be used for human food. The $M$. oleifera leaves powder is known as a nutritious food supplements that can save human life, especially in some countries with poor nutrition people [6].

M. oleifera also contains several important elements for life, plays a role in enzyme activation, conduction of nerve impulse, oxygen transportation, and immunity function. $M$. oleifera is a good protein source rich in minerals, zinc, and, especially, irons [7]. $M$. oleifera is "the Mother's Best Friend" since it can increase breast milk supply and prolactin hormone and is as nutritious tree and medicine [8], [9].

M. oleifera, in Indonesia, is a local tree having the potential to be developed as breastfeeding mothers' 
food. It contains phytosterol (classified into steroids) having a function to increase and accelerate breast milk supply (galactagogue effect) [9], [10]. In this study, the researcher assessed the influence of $M$. oleifera leaves intake in pregnant mothers and breastfeeding mothers on DHA and AA concentrations in breast milk.

\section{Materials and Methods}

This longitudinal study was a continuity of the previous experiment study by providing food supplement in the form of $M$. oleifera in six sub-districts in Jeneponto District. Pregnant mothers on their second trimester participated in this research were divided into three groups consisting of Moringa leaves extract (MLE) group which was given by $500 \mathrm{mg}$ of $M$. oleifera leaves extract, Moringa leaves powder (MLP) group which was given by $500 \mathrm{mg}$ of $M$. oleifera leaves powder and iron folic acids (IFA) group which was given by $60 \mathrm{mg}$ of Fe (IFA), consumed twice a day, respectively. The supplement was given in the form of capsule for 30 days. The subject was divided into three groups.

As many as 64 mothers met the criteria and participated in this research. They consisted of 23 mothers from MLP group, 20 mothers from IFA group, and 21 mothers from MLE group. On the $6^{\text {th }}$ month of their labor, the researcher carried out home visit to collect the breast sample around 8-11 a.m using pigeon breast milk pump which was then put into $7 \mathrm{ml}$ sterile cub and stored at $-80^{\circ} \mathrm{C}$. Furthermore, the breast milk sample was analyzed in the laboratory of Medical Research Center of Universitas Hasanuddin to measure the DHA and AA of the breast milk employing ELISA method using Elisa Reader from Thermo USA brand. Standard questionnaire was used by trained field workers to perform all measurement. The data were then analyzed using Kruskal-Wallis test with the significance level of $95 \%$.

The ethical permit was issued by the Health Research Ethical Committee of the Faculty of Public Health of Universitas Hasanuddin, number: 7694/ UN4.14.8/TP.02.02/2019, August 13, 2019. The subject signed consent before being participated in the research.

\section{Results}

\section{The characteristics of mothers and infants}

Table 1 shows that most of the mothers have low education $(71.9 \%)$, as homemakers $(89.1 \%)$, and their family income is below the regional minimum wage (60.9\%). The percentage of mothers at the age above 26 years old was $70.3 \%$. The percentage of those who had
1-2 children was $57.8 \%$. For those who did not have PNC were $87.5 \%$, while the mothers who did ANC $<4$ times were $65.6 \%$. The percentage of mothers who had a BMI score above 22.9 was $48.4 \%$. Meanwhile, the percentage of anemic mothers in their third trimester of pregnancy was $56.3 \%$. The percentage of mothers with the gestational age in the full-term category was $95.3 \%$. Meanwhile, the percentage of mothers who gave birth in health facilities was $93.8 \%$. There was no significant difference in mothers who were in MLP, MLE, and IFA groups ( $p>0.05)$.

\section{The recommended dietary allowances of breastfeeding mothers}

The breastfeeding mothers' nutritional adequacy rate (Table 2) shows that there was no significant difference between the energy intake $(p=0.871)$, carbohydrate intake $(p=0.711)$, fat intake $(p=0.602)$, and protein intake $(p=0.873)$ among the MLP, MLE, and IFA groups.

\section{Fatty acid content in Moringa powder}

The fatty acid content in MLP is shown in Table 3. Total fatty acid in MLP was $42.12 \%$ from $3.4 \% \mathrm{w} / \mathrm{w}$ fat content. Most of the fatty acid types were linolenic acid (C18:3n3) of $24.25 \%$ and linoleic acid (LA) $(\mathrm{C} 18: 3 \mathrm{n} 6)$ of $2.13 \%$.

The influence of MLP, IFA, and MLE intakes during pregnancy and breastfeeding on the DHA and AA levels of breast milk

Table 4 shows no significant difference in DHA levels of breast milk ( $p=0.215$ ) between MLP group (mean \pm SD; $33.37 \pm 2.29$ ), IFA group (mean \pm SD; $34.87 \pm$ 6.14 ), and MLE group (mean \pm SD; $50.39 \pm 41.35$ ). Besides, there is no significant difference in AA levels of breast milk ( $p=0.914)$ between MLP group (mean \pm SD; $176.5 \pm 97.4)$, IFA group (mean \pm SD; $164.61 \pm 115.73$ ), and MLE group (mean \pm SD; $180.16 \pm 30$ ).

\section{Discussion}

This research provided a little proof that the provision of $M$. oleifera as food supplement during the pregnancy and breastfeeding affected the level of DHA and AA of the mothers' breast milk. In the previous research, there was no long-term effect of the supplementation on the breast milk quality (DHAand AA) although it was proven to be significantly beneficial for the pregnancy (difference of pregnant mothers' anemia status and difference of baby birth weight among the three groups).

Based on the comparison of the mean value of DHA and AA level of breast milk between the intervention 
Table 1: The characteristics of mothers and infants

\begin{tabular}{|c|c|c|c|c|c|c|c|c|c|}
\hline \multirow[t]{2}{*}{ Variables } & \multicolumn{2}{|c|}{$\operatorname{MLP}(n=23)$} & \multicolumn{2}{|c|}{$\operatorname{IFA}(n=20)$} & \multicolumn{2}{|c|}{$\operatorname{MLE}(n=21)$} & \multicolumn{2}{|c|}{ Total $(n=64)$} & \multirow[t]{2}{*}{$p$-value } \\
\hline & $\mathrm{n}$ & $\%$ & $\mathrm{n}$ & $\%$ & $\mathrm{n}$ & $\%$ & $\mathrm{n}$ & $\%$ & \\
\hline Mother's education (years) & & & & & & & & & 0.126 \\
\hline High $(\geq 12)$ & 5 & 21.7 & 9 & 45.0 & 4 & 19.0 & 18 & 28.1 & \\
\hline Low $(<12)$ & 18 & 78.3 & 11 & 55.0 & 17 & 81.0 & 46 & 71.9 & \\
\hline Mother's occupation & & & & & & & & & $0.828^{*}$ \\
\hline Employed & 2 & 8.7 & 2 & 10.0 & 3 & 14.3 & 7 & 10.9 & \\
\hline Unemployed & 21 & 91.3 & 18 & 90.0 & 18 & 85.7 & 57 & 89.1 & \\
\hline Family income (million) & & & & & & & & & 0.876 \\
\hline$\geq 2$ & 9 & 39.1 & 7 & 35.0 & 9 & 42.9 & 25 & 39.1 & \\
\hline$<2$ & 14 & 60.9 & 13 & 65.0 & 12 & 57.1 & 39 & 60.9 & \\
\hline Mother's age (years old) & & & & & & & & & 0.266 \\
\hline$\geq 26$ & 18 & 78.3 & 15 & 75.0 & 12 & 57.1 & 45 & 70.3 & \\
\hline$<26$ & 5 & 21.7 & 5 & 25.0 & 9 & 42.9 & 19 & 29.7 & \\
\hline Total children (children) & & & & & & & & & $0.437^{\star}$ \\
\hline$<3$ & 11 & 47.8 & 12 & 60.0 & 14 & 66.7 & 37 & 57.8 & \\
\hline$\geq 3$ & 12 & 52.2 & 8 & 40.0 & 7 & 33.3 & 27 & 42.2 & \\
\hline PNC & & & & & & & & & $0.311^{*}$ \\
\hline Yes & 1 & 4.3 & 3 & 15.0 & 4 & 19.0 & 8 & 12.5 & \\
\hline No & 22 & 95.7 & 17 & 85.0 & 17 & 81.0 & 56 & 87.5 & \\
\hline ANC (times) & & & & & & & & & 0.814 \\
\hline$\geq 4$ & 9 & 34.1 & 6 & 30.0 & 7 & 33.3 & 22 & 34.4 & \\
\hline$<4$ & 14 & 60.9 & 14 & 70.0 & 14 & 66.7 & 42 & 65.6 & \\
\hline Mother's BMI & & & & & & & & & $0.245^{\star}$ \\
\hline$>22.9$ & 15 & 65.2 & 7 & 35.0 & 9 & 42.9 & 31 & 48.4 & \\
\hline $18.5-22.9$ & 5 & 21.7 & 9 & 45.0 & 10 & 47.6 & 24 & 37.5 & \\
\hline$<18.5$ & 3 & 13.0 & 4 & 20.0 & 2 & 9.5 & 9 & 14.1 & \\
\hline Anemia at the $3^{\text {rd }}$ trimester & & & & & & & & & 0.886 \\
\hline Non-anemic & 13 & 56.5 & 12 & 60.0 & 11 & 52.4 & 36 & 56.3 & \\
\hline Anemic & 10 & 43.5 & 8 & 40.0 & 10 & 47.6 & 28 & 43.8 & \\
\hline Delivery types & & & & & & & & & $0.995^{*}$ \\
\hline Term & 22 & 95.7 & 19 & 95.0 & 20 & 95.2 & 61 & 95.3 & \\
\hline Pre-term & 1 & 4.3 & 1 & 5.0 & 1 & 4.8 & 3 & 4.7 & \\
\hline Place for giving birth & & & & & & & & & $0.832^{*}$ \\
\hline Public/maternity hospital & 21 & 91.3 & 19 & 95.0 & 20 & 95.2 & 60 & 93.8 & \\
\hline House & 2 & 8.7 & 1 & 5.0 & 1 & 4.8 & 4 & 6.3 & \\
\hline
\end{tabular}

Table 2: The nutrition intake of breastfeeding mothers categorized into MLP, IFA, and MLE groups

\begin{tabular}{|c|c|c|c|c|c|c|}
\hline \multirow[t]{2}{*}{ Groups } & \multicolumn{2}{|c|}{ Good } & \multicolumn{2}{|c|}{ Poor } & \multirow{2}{*}{$\begin{array}{l}\text { Calories } \\
\text { Mean } \pm \text { SD }\end{array}$} & \multirow[t]{2}{*}{$p$-value } \\
\hline & $\mathrm{n}$ & $\%$ & $\mathrm{n}$ & $\%$ & & \\
\hline \multicolumn{7}{|l|}{ Energy } \\
\hline $\operatorname{MLP}(n=23)$ & 0 & 0.0 & 23 & 100.0 & $1155.93 \pm 298.07$ & \multirow[t]{3}{*}{$0.871^{* *}$} \\
\hline IFA $(n=20)$ & 3 & 15.0 & 17 & 85.0 & $1234.26 \pm 452.88$ & \\
\hline $\operatorname{MLE}(n=21)$ & 3 & 14.3 & 18 & 85.7 & $1149.58 \pm 58$ & \\
\hline \multicolumn{7}{|l|}{ Carbohydrate } \\
\hline $\operatorname{MLP}(n=23)$ & 0 & 0.0 & 23 & 100.0 & $159.27 \pm 39.48$ & \multirow[t]{3}{*}{$0.711^{\star *}$} \\
\hline $\operatorname{IFA}(n=20)$ & 0 & 0.0 & 20 & 100.0 & $153.60 \pm 39.95$ & \\
\hline $\operatorname{MLE}(n=21)$ & 1 & 4.8 & 20 & 95.2 & $151.97 \pm 50.32$ & \\
\hline \multicolumn{7}{|l|}{ Fat } \\
\hline $\operatorname{MLP}(n=23)$ & 7 & 30.4 & 16 & 69.6 & $38.27 \pm 21.68$ & \multirow[t]{3}{*}{$0.602^{\star *}$} \\
\hline IFA $(n=20)$ & 7 & 35.0 & 13 & 65.0 & $50.68 \pm 37.84$ & \\
\hline $\operatorname{MLE}(n=21)$ & 4 & 19.0 & 17 & 81.0 & $40.49 \pm 32.20$ & \\
\hline \multicolumn{7}{|l|}{ Protein } \\
\hline $\operatorname{MLP}(n=23)$ & 7 & 30.4 & 16 & 69.6 & $42.51 \pm 13.17$ & \multirow[t]{3}{*}{$0.873^{*}$} \\
\hline IFA $(n=20)$ & 5 & 25.0 & 15 & 75.0 & $40.82 \pm 8.77$ & \\
\hline $\operatorname{MLE}(n=21)$ & 7 & 33.3 & 14 & 66.7 & $43.05 \pm 18.88$ & \\
\hline
\end{tabular}

groups, the mothers who got MLE had higher DHA level compared to the mothers who got MLP and IFA. However, based on the distribution, the breast milk's

Table 3: The fatty acid levels in Moringa oleifera leaves

\begin{tabular}{ll}
\hline Fat content & $(\% \mathrm{w} / \mathrm{w})$ \\
\hline Fat content & 3.74 \\
Fatty acid & 0.35 \\
Lauric acid, C12:10 & 0.55 \\
Myristic acid C14:0 & 0.20 \\
Myristoleic acid, C14:1 & 0.05 \\
Pentadecanoic acid, C15:0 & 9.41 \\
Palmitic acid, C16:0 & 0.15 \\
Palmitoleic acid, C16:1 & 0.07 \\
Heptadecanoic acid, C17:0 & 0.02 \\
Cis-10-heptadecanoic acid, C17:1 & 1.11 \\
Stearic acid, C18:0 & 1.95 \\
Oleic acid, C18:1n9c & 2.13 \\
Linoleic acid, C18:2n6c & 0.31 \\
Arachidic acid, C20:0 & 0.19 \\
r-Linolenic acid, C18:3n6 & 24.25 \\
Linolenic acid, C18:3n3 & 0.46 \\
Behenic acid, C22:0 & 0.06 \\
Cis-11,14,17-eicosatrienoic acid methyl ester, (C20:3n3) & 0.09 \\
Tricosanoic acid, C23:0 & 0.77 \\
Lignoceric acid, C24:0 & 42.12 \\
Fatty acid total &
\end{tabular}

Table 4: The difference in DHA and AA levels of breast milk in breastfeeding mothers who consume MLP, IFA, and MLE

\begin{tabular}{|c|c|c|c|c|}
\hline \multirow[t]{2}{*}{ Variables } & $\operatorname{MLP}(n=23)$ & IFA $(n=20)$ & $\operatorname{MLE}(n=21)$ & \multirow[t]{2}{*}{ p-value } \\
\hline & Mean \pm SD & Mean $\pm S D$ & Mean $\pm S D$ & \\
\hline DHA pg/mL & $33.37 \pm 2.29$ & $34.87 \pm 6.14$ & $50.39 \pm 41.35$ & 0.215 \\
\hline AA ug $/ \mathrm{mL}$ & $176.5 \pm 97.4$ & $164.61 \pm 115.73$ & $180.16 \pm 96.30$ & 0.914 \\
\hline
\end{tabular}

DHA level of the MLE group was seen to more stable compared to the other two groups. Nevertheless, there was no significant difference regarding the DHA level of the breast milk of the three groups.

The mothers who got $M$. oleifera extract also have higher mean value of breast milk's AA compared to the mothers who obtained M. oleifera Lamk and IFA. However, the distribution of AA level of the IFA group was more stable compared to MLP and MLE groups. Nevertheless, there was no significant difference of the level of breast milk DHA and AA between the three groups. On the other words, each intervention capsule generally has function which is not far different from each other in affecting the level of breast milk DHA and AA level. It means that all capsules have the same contribution in affecting the level of breast milk DHA and AA.

M. oleifera Lamk was provided to pregnant and breastfeeding mothers, containing alpha-linolenic acid (ALA) by $24.25 \% \mathrm{w} / \mathrm{w}$ and LA by $2.13 \% \mathrm{w} / \mathrm{w}$. This content is relatively low compared to the dried $M$. oleifera content in South Africa which has $\alpha$-linolenic acid by $44.57 \%$ and linoleic acid by $7.44 \%$ [11]. Meanwhile, according to the research conducted by Saini et al., the extract of Indian variety-M. oleifera contains $54.27 \%$ ALA and $11.01 \%$ LA from the total fatty acid [12]. Both M. oleifera Lamk and extract have higher ALA content than LA content. 
Long chain polyunsaturated fatty acid (LA and ALA) is converted into DHA and AA in the body through desaturation and carbon chain extension (elongation).

There are several factors that can affect the conversion of ALA to EPA and DHA including diet and genetic factors, other nutrition deficiency, gender differences, and polymorphism on the desaturation and elongation. During the biosynthesis of LC-PUFA, the LA and ALA compete to each other for the elongation and desaturation, thus the low ratio of LA supports more on the biosynthesis of n-3 LC-PUFA than ALA (13). In this study, the ALA content of the M. oleifera Lamk and Extract was higher that $L A$ so that the supplementation of $M$. oleifera Lamk and extract supports the $n 3$ long chain polyunsaturated fatty acid (LCPUFA) biosynthesis.

DHA can be synthesized from ALA. However, such process is very limited to be carried out on human with the conversion level as low as $0.25-7.0 \%$ for EPA and $0.01-0.05 \%$ for DHA causing the DHA is relatively low in the body [13] but it is regulated on pregnant mothers and [14]. In general, the contribution of fatty acid in breast milk is obtained from diet by $29 \%$, biosynthesis by $11 \%$ or joints in tissue by $59 \%$ [15], [16]. Therefore, the fatty acid of breast milk is particularly sourced from the mothers' joints and diet, while a little amount of the breast milk $A A$ and $D H A$ is from the endogen synthesis of EFA precursor [17].

The difference between DHA and AA level obtained through $M$. oleifera supplement found in this research did not have any long-term contribution on the mothers' breast milk in their first 6 months breastfeeding after the intervention. The same result was obtained by the previous longitudinal research conducted by Dustan in West Australia that the provision of fish oil on pregnant mothers for 20 weeks until the labor did not have any long-term effect on the composition of LCPUFA on the breast milk [18]. It was also in line with the research performed by Jensen on breastfeeding mothers consuming algae, egg, and fish oil, in which there was no significant difference between the three groups on the concentration of $n 3$ or n6 fatty acids observed in the first 6 weeks after the intervention [19]. The same result was also found by Urwin that mother who consumed salmon during their pregnancy increased the total LCPUFA significantly on the breast milk during the initial breastfeeding. However, such effect could only be maintained for 1 month after the salmon consumption cessation [20].

Different result was reported by van Goor et al. stating that the mothers who obtained $A A+D H A$ supplement $(220 \mathrm{mg} /$ day) increased their breast milk AA $\left(2^{\text {nd }}\right.$ week was by $14 \%$, and the $12^{\text {th }}$ week by $\left.23 \%\right)$ and $\mathrm{DHA}(43 \%$ and $52 \%)$ compared to placebo [17]. Other research result was reported by Smit et al. that the provision of combination supplementation of $300 \mathrm{mg} \mathrm{AA}$ and $400 \mathrm{mg}$ DHA and 110 EPA tended to increase $A A$ of the breast milk and long chain PUFA level of $n 3$ [21].
Therefore, the low biosynthesis of DHA and $\mathrm{AA}$ as well as DHA and $\mathrm{AA}$ augmentation of the breast milk during the breastfeeding is at best by consuming formed DHA and AA [22]. The consumption of exogen DHA and AA of has bigger contribution that endogen synthesis results so that it is beneficial for the mother to directly consume DHA and AA source. However, several factors are suggested to affect the breast milk composition including the breastfeeding steps, parity, pregnancy age, mothers' diet, breastfeeding time, mothers' body composition, and mothers' genetic and baby possible factors such as gender [23].

In this research, the nutrition intake of the breastfeeding mothers is generally low including the good pattern of DHA source consumption. Although a part of Jeneponto District is coastal area, the community is rarely exposed to seafood source. This is due to the low knowledge level and the purchasing power of the community. Therefore, the local food such as M. oleifera which is beneficial for the pregnant mothers both during their pregnancy and avoiding harmful pregnancy outcome [24], can be an alternative in improving the community's nutrition. The finding of this study is in line with the previous study which demonstrated that Moringa oleifera extract in lactating mothers could positively affect nutritional status of the infants [4]. In addition to become nutritional food supplement, this plant is also easily obtained in tropical and subtropical area in the world [9], [25].

\section{Conclusion}

M. oleifera extract might affect the level of DHA and $A A$ in the breast milk. Therefore, we do recommend that the government uses $M$. oleifera leaves as the local sources to improve the quality of the breast milk of the lactating mothers in Jeneponto Regency.

\section{Acknowledgments}

The authors would like to express the deepest gratitude to the families and infants who have participated in this study and Universitas Hasanuddin Hospital that has provided laboratory support.

\section{References}

1. Antonakou A, Skenderi KP, Chiou A, Anastasiou CA, Bakoula C Matalas AL. Breast milk fat concentration and fatty acid pattern 
during the first six months in exclusively breastfeeding Greek women. Eur J Nutr. 2013;52(2):963-73. https://doi.org/10.1007/ s00394-012-0403-8

PMid:22752261

2. Ribeiro M, Balcao V, Guimaraes H, Rocha G, Moutinho C, Matos $\mathrm{C}$, et al. Fatty acid profile of human milk of portuguese lactating women: Prospective study from the $1^{\text {st }}$ to the $16^{\text {th }}$ week of lactation. Ann Nutr Metab. 2008;53(1):50-6. https://doi. org/10.1159/000156597

PMid: 18802330

3. Keim SA, Nancy D, Peter CS. Breastfeeding and long-chain polyunsaturated fatty acid intake in the first 4 post-natal months and infant cognitive development: An observational study. Matern Child Nutr. 2012;8(4):471-82. https://doi. org/10.1111/j.1740-8709.2011.00326.x PMid:21615865

4. Hadju V. Infant nutritional status of 0-6 months of exclusive breastfeed due to the application of Moringa leaf extract in breastfeeding mothers Health Notions. 2018;2(6):669-74.

5. Nadimin N. Pengaruh Pemberian Ekstrak Daun Kelor Terhadap Pencegahan Anemia, Kerusakan DNA Oksidatif Pada Ibu Hamil Dan Berat Badan Lahir.. Makassar: Program Pascasarjana Universitas Hasanuddin; 2015.

6. Stadtlander T, Becker K. Proximate composition, amino and fatty acid profiles and element compositions of four different Moringa species. J Agric Sci. 2017;9(7):46. https://doi.org/10.5539/jas. v9n7p46

7. Alrawashdeh NQ, Alrawashdeh IM, Alzghoul TM. Amino acids and mineral composition analysis of Moringa peregrina forssk (fiori) in Jordan. ARPN J Agric Biol Sci. 2016;11(5):175-9.

8. Taup MA. Moringa oleifera. Philipp J Pediatr. 2000;49(1):3-6.

9. Chukwuebuka E. Moringa oleifera the mother's best friend. Int J Nutr Food Sci. 2015;4(6):624. https://doi.org/10.11648/j. ijnfs.20150406.14

10. Sulistiawati $Y$, Suwondo A, Hardjanti TS, Soejoenoes A, Anwar MC, Susiloretni KA. Effect of Moringa oleifera on level of prolactin and breast milk production in postpartum mothers. Belitung Nurs J. 2017;3(2):126-33. https://doi.org/10.33546/ bnj.75

11. Busani M, Patrick JM, Arnold H, Voster M. Nutritional characterization of Moringa (Moringa oleifera Lam.) leaves. Afr J Biotechnol. 2011;10(60):12925-33. https://doi.org/10.5897/ ajb10.1599

12. Saini RK, Shetty NP, Giridhar P. GC-FID/MS analysis of fatty acids in Indian cultivars of Moringa oleifera: Potential sources of PUFA. J Am Oil Chem Soc. 2014;91(6):1029-34. https://doi. org/10.1007/s11746-014-2439-9

13. Saini RK, Keum YS. Omega-3 and omega-6 polyunsaturated fatty acids: Dietary sources, metabolism, and significance-a review. Life Sci. 2018;203:255-67. https://doi.org/10.1016/j. Ifs.2018.04.049

PMid:29715470

14. Andersen KR, Harslof LB, Schnurr TM, Hansen T, Hellgren LI, Michaelsen KF, et al. A study of associations between early DHA status and fatty acid desaturase (FADS) SNP and developmental outcomes in children of obese mothers. Br J Nutr. 2017;117(2):27886. https://doi.org/10.1017/s0007114516004645 PMid:28162103

15. Thompson BJ, Smith S. Biosynthesis of fatty acids by lactating human breast epithelial cells: An evaluation of the contribution to the overall composition of human milk fat. Pediatr Res. 1985;19(1):139-43. https://doi. org/10.1203/00006450-198501000-00036

PMid:3969307

16. Hachey DL, Thomas MR, Emken EA, Garza C, BrownBooth L, Adlof RO, et al. Human lactation: Maternal transfer of dietary triglycerides labeled with stable isotopes. J Lipid Res. 1987;28(10):1185-92.

PMid:3681142

17. van Goor SA, Dijck-Brouwer DA, Hadders-Algra M, Doornbos B, Erwich JJ, Schaafsma A, et al. Human milk arachidonic acid and docosahexaenoic acid contents increase following supplementation during pregnancy and lactation. Prostaglandins Leukot Essent Fatty Acids. 2009;80(1):65-9. https://doi.org/10.1016/j.plefa.2008.11.002

PMid:19118992

18. Dunstan JA, Mitoulas LR, Dixon G, Doherty DA, Hartmann PE, Simmer $\mathrm{K}$, et al. The effects of fish oil supplementation in pregnancy on breast milk fatty acid composition over the course of lactation: A randomized controlled trial. Pediatr Res. 2007;62(6):689-94. https://doi.org/10.1203/ pdr.0b013e318159a93a PMid:17957152

19. Jensen CL, Maude M, Anderson RE, Heird WC. Effect of docosahexaenoic acid supplementation of lactating women on the fatty acid composition of breast milk lipids and maternal and infant plasma phospholipids. Am J Clin Nutr. 2000;71(1):292-9. https://doi.org/10.1093/ajcn/71.1.292s

PMid:10617985

20. Urwin HJ, Miles EA, Noakes PS, Kremmyda LS, Vlachava M, Diaper ND, et al. Salmon consumption during pregnancy alters fatty acid composition and secretory IgA concentration in human breast milk. J Nutr. 2012;142(8):1603-10. https://doi. org/10.3945/jn.112.160804

PMid:22739373

21. Smit EN, Koopmann M, Boersma ER, Muskiet FA. Effect of supplementation of arachidonic acid (AA) or a combination of AA plus docosahexaenoic acid on breastmilk fatty acid composition. Prostaglandins Leukot Essent Fatty Acids. 2000;62(6):335-40. https://doi.org/10.1054/plef.2000.0163 PMid:10913225

22. Brenna JT, Diau GY. The influence of dietary docosahexaenoic acid and arachidonic acid on central nervous system polyunsaturated fatty acid composition. Prostaglandins Leukot Essent Fatty Acids. 2007;77(5-6):247-50. https://doi. org/10.1016/j.plefa.2007.10.016 PMid: 18023566

23. Stam J, Sauer PJ, Boehm G. Can we define an infant's need from the composition of human milk? Am J Clin Nutr. 2013;98(2):521S-8. https://doi.org/10.3945/ajcn.112.044370 PMid:23842459

24. Nurdin MS, Imam A, Thahir A, Hadju V. Supplementations on pregnant women and the potential of Moringa oleifera supplement to prevent adverse pregnancy outcome. Int J Sci Healthc Res. 2018;3(1):71-5.

25. Olaofe OI, Adeyeye E, Ojugbo S. Comparative study of proximate amino acids and fatty acids of Moringa oleifera tree. Elixir Appl Chem. 2013;54:12543-54. 